\title{
Determinants Of Enforcement Action By The Financial Supervisory Service Of Korea From The Perspective Of Audit Firms
}

\author{
Min-Jung Kang, Incheon National University, South Korea \\ Ho-Young Lee, Yonsei University, South Korea \\ Yong-Sang Woo, Ewha Womans University, South Korea
}

\begin{abstract}
In this study, we examine the determinants of enforcement action by the Financial Supervisory Service of Korea from the perspective of audit firms. Enforcement action is an indication of audit failure. Both clientand audit firm-specific factors are involved in its occurrence. Most published studies of enforcement after audit failure focus on client characteristics because details about audit firms from financial statements and information about organizational structure are not publicly available. However, examining the issues surrounding enforcement from the perspective of audit firms may also be valuable in elucidating the potential determinants of audit failure resulting in enforcement action. Utilizing publicly available data from audit firms in South Korea, we identify several audit firm characteristics as determinants of enforcement action. The results of our empirical analysis reveal that the likelihood of audit failure is positively associated with the ratio of accounts receivable to total assets, the ratio of audit fees to total revenue, the ratio of partners to the total number of CPAs, CEO ownership, and age of audit firms. In addition, the likelihood of audit failure is negatively associated with ownership concentration and profitability. These associations are more pronounced in non-affiliated audit firms than affiliated audit firms. Several useful implications for regulators are described for improving audit quality by means of enforcement action.
\end{abstract}

Keywords: Enforcement Action; Financial Supervisory Service Of Korea; Audit Firms

\section{INTRODUCTION}

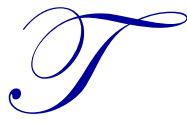

he interest of stakeholders in audit failure increased after the Enron scandal in 2001. Since then, numerous studies have been conducted on determinants of audit failure (e.g., Palmrose 1988; St. Pierre and Anderson 1984; Stice 1991; Lys and Watts 1994; Pratt and Stice 1994; Bell et al. 2001; Abbott et al. 2006). These studies tend to be written from the perspectives of audit clients instead of audit firms. Of the few studies that have examined audit failure from the perspective of audit firms, most have focused on the association between audit failure and audit firm size (e.g., Palmrose 1988; Lennox 1999). However, many other factors may be involved in determining whether or not an audit is successful. Audit failure occurs when an audit firm fails to control audit risk at an appropriate level. Audit risk is the joint probability of inherent risk, control risk, and detection risk (PCAOB No.8). While inherent and control risk are client-specific, detection risk is audit firmspecific. Thus, both perspectives must be considered for a comprehensive understanding of the determinants of audit failure: that of audit clients and that of audit firms.

In our study, we empirically investigate the determinants of audit failure as indicated by the presence of enforcement action. We particularly focus on the independence, expertise, governance, and financial structure of audit firms as factors affecting audit failure. Prior researchers have reported that independence and industry expertise in audit firms are positively associated with audit quality (e.g., DeAngelo 1981; Balsam et al. 2003). In addition, the association between governance of audit clients and earnings management as an indication of audit risk has also been empirically analyzed (Dechow et al. 1996; Beasley 1996; Klein 2002). However, audit firm governance has not been examined as a determinant of audit failure. As with any firm, the governance of audit firms 
is expected to influence the likelihood of audit failure. In our study, we provide an empirical analysis of the role of audit firm governance in audit failure. In addition, although the association between the financial structure of audit clients and earnings management has been adequately analyzed (Healy and Palepu 1990; DeFond and Jiambalvo 1994), the association between the financial structure of audit firms and audit failure has rarely been studied.

Using 496 audit-firm years from the period from 2003 to 2009, we examine important characteristics of audit firms that may be associated with audit failure, as indicated by the presence of enforcement action. The results of our study show that the ratio of accounts receivable to total assets $(R E C)$ and the ratio of audit fees to total revenue $(A F R)$ are positively associated with audit failure. We also find evidence that the ratio of audit partners to the total number of employees is positively associated with audit failure. This result may suggest that the likelihood of audit failure increases when partners have relatively few staff engaged in an audit. Finally, we find evidence that audit failure is positively associated with CEO ownership $(O W N)$ and the number of years from foundation, and negatively associated with ownership concentration $(L H H)$ and profitability (ROS_auditor).

Our study extends the body of research on audit failure by considering additional characteristics of audit firms, the details of which are available in Korea. ${ }^{1}$ In addition to client characteristics, audit firm characteristics are also expected to affect audit failure. In earlier studies, the roles of various important audit firm characteristics in audit failure could not be considered primarily because of the lack of publicly available data about audit firms. We include the following factors in our investigation of audit failure: independence, expertise, financial structure, and governance of audit firms. Our measure of audit failure is ex-post, which is more accurate than ex-ante proxies for audit failure. We examine data for firms that were subject to surveillance sanctions and the frequency of those sanctions by the Financial Supervisory Service of Korea (the Korean equivalent to the U.S. SEC).

Our study is organized as follows: in section II, a review of related literature is conducted. In section III, the hypotheses of the study and empirical models are presented. In section IV, the sample and results of the analyses are discussed. Finally, section V summarizes the results and concludes the study.

\section{LITERATURE REVIEW AND HYPOTHESES}

Previous studies on audit failure can be classified as ex-ante or ex-post facto. An ex-ante measurement of audit failure has the limitation that it cannot reflect the actual occurrence and frequency of audit failure. For that reason, in the majority of previous studies, ex-post audit failure is measured. Using the number of lawsuits against audit firms as a measure, for example, Palmrose (1988) discovered that as the size of the audit firm (Big 8/non-Big 8) increases, the likelihood of audit failure also increases. Stice (1991) also adopted the number of lawsuits against audit firms as a measure of ex-post audit failure in an empirical analysis of the determinants of audit failure. He reported that asset structure, financial condition, market value, and return volatility of clients affect audit failure risk. In order to investigate determinants of audit failure, Lys and Watts (1994) compared the characteristics of clients who were accused of earnings management with clients who were not. They showed that audit failure is associated with the stock price performance of audit clients, their size, the structure of their audits, the presence or absence of a qualified auditor's opinion, and the proportion of audit revenues derived from the client. Casterella et al. (2010) reported that audit failure may be affected by the size and growth rate of the audit firm and whether or not the audit firm accuses the audit client of earnings management.

Several studies used proxies for ex-ante audit failure. For example, Schultz and Gustavson (1978) argued that the likelihood of audit failure as perceived by actuaries increases as the size of audit firms and number of clients increase. Linville and Thornton (2001) investigated risk factors considered by insurance firms, reporting that in evaluating risk factors of audit firms, insurance firms consider several characteristics of audit firms, including gross revenue, the diversity of services in proportion to total revenue, the opportunity for ongoing professional education, and the peer review policy. In this study, we use two proxies for ex-post audit failure: sanctioning of an audit firm by

\footnotetext{
${ }^{1}$ In the U.S., the Public Company Accounting Oversight Board (PCAOB) Rule 2200-2207 and The Sarbanes Oxley Act of 2002, Section 102 (d) require that accounting firms disclose information about their firms. Unlike in Korea, accounting firms are not required to disclose details of financial statements and human and organizational structures.
} 
the Financial Supervisory Service of Korea (FSS, hereafter) and the frequency of enforcement action taken against an audit firm.

Most studies include analysis of the causes of enforcement action and suggest solutions from the perspective of audit clients. Using sample firms subject to enforcement action by the SEC, Dechow et al. (1996) discovered that the main motive of earnings manipulation is to raise capital at low cost. Additionally, they reported that in most firms in which earnings are manipulated, managers dominate the board of directors, the CEO is also the chairman of the board of directors, the CEO is the founder of the firm, and major external stockholders are lacking. Analyzing the SEC's Accounting and Auditing Enforcement Releases, Beneish (1999) also found that managers of M\&A target firms experienced SEC enforcement action tend to sell their stocks or stock appreciation rights more frequently than the managers of control firms when earnings are overstated and products are sold at inflated prices. Similarly, Nourayi (1994) reported that enforcement action by the SEC resulted in a negative reaction to stock returns.

Several scholars examined audit failure from the perspective of audit firm characteristics. For example, Feroz et al. (1991) reported an association between enforcement action and insufficient collection of audit evidence, failure to perform audit procedures correctly, and failure to confirm clients' arguments. Hermanson et al. (2007) analyzed inspections of the PCAOB conducted in 316 small accounting firms. They reported that audit quality was low when the number of audit clients was large and the growth rate of audit firms was high. Unlike these prior studies, we consider more comprehensive and important audit firm characteristics, including several proxies for independence, expertise, governance structure, and financial structure of audit firms.

Both audit clients and audit firms play a role in audit failure. Audit quality is defined as the degree to which errors in the financial statement are discovered and the extent to which the discovered errors are reported (DeAngelo 1981). The former is affected by expertise in the audit firm, and the latter is affected by its independence. When expertise is good and independence is sufficient, errors are less likely to occur and more likely to be discovered and reported. In our study, audit failure is measured according to whether or not accounting firms were subject to enforcement action by the FSS.

We use the ratio of accounts receivable to total assets and the proportion of audit fees of total revenue as proxy variables for the independence of audit firms. If the ratio of accounts receivable to total assets increases, audit firms may experience operating difficulties in the short run, which increases their incentive to take on clients who are seeking unqualified opinions and accept early payment of higher audit fees. Consistent with this, the Code of Ethics for the Certified Public Accountants of Korea states that audit firms may be behaving opportunistically when this ratio is high. ${ }^{2}$ Accordingly, as the proportion of accounts receivable to total assets increases, the independence of audit firms decreases. Thus, the likelihood of enforcement action by the FSS is predicted to be positively associated with the proportion of accounts receivable to total assets. Hypothesis 1 is therefore stated as follows:

Hypothesis 1: The ratio of accounts receivable to total assets of the audit firm is positively associated with the likelihood of enforcement action by the Financial Supervisory Service of Korea.

When the ratio of revenues from audit fees to total revenue of audit firms is high, there is an incentive to maintain audit contracts at the expense of independence. When sources of revenue are not diversified, retaining audit clients becomes more important than otherwise. Under those conditions, audit firm independence decreases. Thus, when the ratio of audit fees to total revenues is high, the possibility of sanctioning by the FSS increases. In addition, audit firm independence may improve because the firm's dependence on non-audit fees is minimal (Frankel et al. 2002). Thus, Hypothesis 2 is stated in the null form as follows:

Hypothesis 2: The proportion of audit fees to total revenues of an audit firm is not associated with the likelihood of enforcement action by the Financial Supervisory Service of Korea.

\footnotetext{
${ }^{2}$ Delayed Fee statute 290.208 in The Code of Ethics for Certified Public Accountants reads as follows: When an important proportion of the fee that was requested to a client for a professional service is not collected for a long time, particularly until the issue of the next year's certification report, the audit firm may be behaving opportunistically. The service provider must therefore collect this fee well in advance of the issue of the subsequent year's certification report.
} 
The expertise of an audit firm increases as more partners who have longer experience are present in an audit firm. Thus, we use the proportion of partners from the total number of CPAs in an audit firm as a proxy for expertise in audit firms. The quality control manual of the FSS promotes partners' participation in individual audit work in order to secure high-quality audits because partners possess relevant knowledge and experience. Thus, we anticipate that enforcement action by the FSS will be less likely as the proportion of partners of all CPAs in an audit firm increases.

On the other hand, other team members of the engagement team also play an important role in the audit because partners are unable to perform the entire audit themselves. If the number of team members is relatively small compared to the number of partners who engage in client development, audit quality could decrease due to work overload. Furthermore, partners may lack understanding of current issues in the audit process because they may seldom engage in the detailed audit process. Thus, the likelihood of enforcement action by the FSS may increase as the proportion of partners of all CPAs in an audit firm increases. These conflicting arguments lead us to Hypothesis 3 (stated in the null form):

Hypothesis 3: The proportion of partners to the total number of CPAs in an audit firm is not associated with the likelihood of enforcement action by the Financial Supervisory Service of Korea.

The governance structure of audit firms may also affect audit failure. Maijoo and Vanstraelen (2012) highlighted the importance of governance in audit firms, which may influence the behaviors of individual CPAs and, ultimately, quality control. CEOs of audit firms have considerable influence on their quality control policies. The Korean Standard on Quality Control also states that CEOs must play a key role in quality control in the daily operations of audit firms.

When CEOs have a high percentage of ownership in the company, agency costs are lower (Jensen and Meckling 1976). Thus, CEOs with a higher percentage of ownership are more likely to exercise stronger quality control over the firm's activities. When quality control is enhanced, the likelihood of audit failure decreases. On the other hand, a strong CEO influence may decrease the efficiency and effectiveness of engagement-level decisions and activities conducted by the audit team under the guidance of an engagement partner. Reduced efficiency and effectiveness may lower audit quality, which in turn increases the likelihood of audit failure. Based on the above arguments, Hypothesis 4 is stated in the null form as follows:

Hypothesis 4: The percentage of shares owned by the CEO is not associated with the likelihood of enforcement action by the Financial Supervisory Service of Korea.

We use partners' ownership concentration as a proxy for governance of audit firms. We measure this variable using the percentage of the company owned by the top five partners. Unlike corporations, audit firms are formed as limited liability companies. Accordingly, there is a limitation on selling or acquiring additional shares. Thus, large changes in ownership percentage rarely occur. For this reason, partners with high ownership have strong influence over operating policies and decision-making.

The ownership concentration variable measures how much the ownership of an audit firm is concentrated on a few partners. If the ownership is concentrated on only a few partners, those partners could have strong influence on the audit firm and the effectiveness of its quality control activities. Accordingly, if the ownership percentage is higher, audit quality improves. On the other hand, if these partners make decisions that further their own private interests, not for the purpose of improving audit quality, audit quality may decline. Based on these competing arguments, we state Hypothesis 5 in the null form as follows:

Hypothesis 5: Ownership concentration is not associated with the likelihood of enforcement action by the Financial Supervisory Service of Korea.

We investigate the association between the age of audit firms and audit failure because firm age is related to the type of operation or governance structure of audit firms. The efficiency and effectiveness of the quality control system of audit firms may improve as they gain more experience. Furthermore, their reputation is likely to improve 
over time. However, if an audit firm retains conventional and formal audit practices, its age has only a limited effect on the prevention of accounting fraud. In addition, newly established audit firms are likely to invest more resources in advanced audit systems in order to build a reputation for providing high-quality services. As competition in the audit market intensifies, newly established audit firms invest more in quality control to increase competitiveness and improve audit quality. Based on these competing arguments, Hypothesis 6 is stated in the null form as follows:

Hypothesis 6: The age of an audit firm is not associated with the likelihood of enforcement action by the Financial Supervisory Service of Korea.

An audit firm's profitability may also affect audit quality. If profitability is low, the firm may accept clients who are opinion-shopping. Unprofitable audit firms are likely to experience difficulty allocating enough time and effort to provide quality audits to their clients, thus increasing the likelihood of audit failure. Therefore, the profitability of audit firms is positively associated with audit failure. In this study, audit firms' profitability is measured using the ratio of net income to total revenue. In accordance with this discussion, Hypothesis 7 is stated in the alternative form as follows:

Hypothesis 7: Profitability is negatively associated with the likelihood of enforcement action by the Financial Supervisory Service of Korea.

\subsection{Research Model}

\section{RESEARCH DESIGN}

In order to test the hypotheses stated above, we use the following research model.

$$
\begin{aligned}
\text { SURV }_{t}=\beta_{0}+ & \beta_{1} R E C_{t-1}+\beta_{2} \text { AFR }_{t-1}+\beta_{3} \text { PAR }_{t-1}+\beta_{4} O W N_{t-1}+\beta_{5} L_{H H} H_{t-1}+\beta_{6} \text { FYEAR }_{t-1} \\
& +\beta_{7} \text { ROS_auditor } \\
& +\beta_{11} \text { SIZE_auditor } \\
& +\beta_{8} \text { SIZE }_{t-1}+\beta_{12} \text { MEM }_{t-1}+\sum \mathrm{YD}
\end{aligned}
$$

where

$S U R V_{\mathrm{t}}: 1$ if enforcement action by the FSS was taken in the current or previous years, and 0 otherwise;

$R E C_{\mathrm{t}-1}$ : accounts receivable / total assets in year $\mathrm{t}-1$;

$A F R_{\mathrm{t}-1}$ : audit fee revenue / total revenue in year $\mathrm{t}-1$;

$P A R_{\mathrm{t}-1}$ : number of partners / total number of CPAs in year $\mathrm{t}-1$;

$O W N_{\mathrm{t}-1}$ : ownership percentage of CEO in year $\mathrm{t}-1$

$L H H_{\mathrm{t}-1}$ : index of ownership concentration computed based on (= ownership of partner with the highest ownership

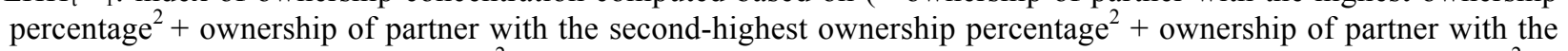
third-highest ownership percentage ${ }^{2}+$ ownership of partner with the fourth-highest ownership percentage ${ }^{2}+$ ownership of partner with the fifth-highest ownership percentage ${ }^{2}$ ) / (highest ownership percentage + second-highest ownership percentage + third-highest ownership percentage + fourth-highest ownership percentage + fifth-highest ownership percentage $)^{2}$ in year $\mathrm{t}-1$;

FYEAR $R_{\mathrm{t}-1}$ : number of years from the establishment of an audit firm / average number of years from establishment of all audit firms in year $\mathrm{t}-1$;

ROS_auditor $\mathrm{t}_{\mathrm{t}-1}$ : net income / total revenue in year $\mathrm{t}-1$;

SIZE_client $t_{\mathrm{t}-1}$ : mean value of the natural logarithm of audit clients' total assets for each audit firm in year $\mathrm{t}-1$; 
ROA_client $t_{\mathrm{t}-1}$ : mean value of audit clients' return on assets for each audit firm in year $\mathrm{t}-1$;

$N L I S T_{\mathrm{t}-1}$ : number of listed audit clients / total number of audit clients in year $\mathrm{t}-1$;

SIZE_auditor $r_{\mathrm{t}-1}$ : natural logarithm of an audit firm's total revenue in year $\mathrm{t}-1$;

$M E M_{\mathrm{t}-1}: 1$ if an audit firm is affiliated with a foreign multinational audit firm, and 0 otherwise in year $\mathrm{t}-1$; and

$Y D$ : year dummy.

The dependent variable in the model is $S U R V$, a dummy variable representing whether or not an audit firm was sanctioned by the FSS in the current year or the previous year. Among the independent variables, the ratio of accounts receivable to total assets, $R E C$, is used to test Hypothesis 1 . Its coefficient, $\beta_{l}$, is expected to be positive because the likelihood of enforcement action increases as $R E C$ increases. The proportion of audit fee revenue to total revenue, $A F R$, is an independent variable used to test Hypothesis 2. The proportion of the number of partners to the total number of CPAs $(P A R)$, total ownership percentage of CEOs $(O W N)$, ownership concentration $(L H H)$, and audit firm age $(F Y E A R)$ are used to test Hypotheses 3, 4, 5, and 6, respectively. Finally, audit firm profitability (ROS_auditor) is used to test Hypothesis 7.

The quality of financial statements is directly affected by client firms that take responsibility for preparing and reporting their own financial statements (Dechow et al. 1996). Thus, client size, profitability, and listing on the stock market are included as control variables in our empirical model. The analyses of this study are conducted at the audit firm level. Accordingly, SIZE_client and ROA_client are measured using the mean values of audit clients for each audit firm. The ratio of listed firms out of all audit clients for each audit firm is included as a control variable because the likelihood of enforcement action increases as the number of listed firms of audit clients increases. The size of audit firms (SIZE_auditor) and affiliation with a multinational audit firm (MEM) are also included as control variables because audit quality may be affected by the size of audit firms (Palmrose 1998). ${ }^{3}$

\subsection{Sample Selection}

The sample period covers the years from 2003 to 2009. Audit firm data became available as of 2003 in Korea. The initial sample consists of 643 audit firm-years. Among these, 48 audit firm-years in which data in financial statements are insufficient and 99 audit firm-years with no listed audit clients are excluded. The FSS of Korea oversees audit firms in terms of enforcement action only with listed clients. Thus, the final sample size is 496 audit firm-years. The sample selection procedures are provided in Panel A of Table 1.

\footnotetext{
${ }^{3}$ Analysis using an indicator representing one of the Big 4 audit firms instead of firms affiliated with a multinational audit firm produces qualitatively the same results as those using MEM.
} 
Table 1. Sample Selection and Distribution

\begin{tabular}{|c|c|c|c|c|c|c|}
\hline \multicolumn{7}{|c|}{ Panel A. Sample Selection Procedure } \\
\hline \multirow{3}{*}{\multicolumn{5}{|c|}{$\begin{array}{l}\text { All audit firm-years during the period } 2003-2009 \\
\text { (Less) Audit firms without data necessary to define explanatory value } \\
\text { (Less) Audit firms which do not have listed clients }\end{array}$}} & \multicolumn{2}{|l|}{643} \\
\hline & & & & & \multicolumn{2}{|l|}{48} \\
\hline & & & & & \multirow{2}{*}{\multicolumn{2}{|c|}{$\frac{99}{496}$}} \\
\hline \multicolumn{5}{|c|}{ Final sample size used for testing the hypothesis } & & \\
\hline \multicolumn{7}{|c|}{ Panel B. Sample by Year } \\
\hline \multirow[t]{2}{*}{ Year } & \multicolumn{2}{|c|}{ Total Sample } & \multicolumn{2}{|c|}{ SURV = o Sample } & \multicolumn{2}{|c|}{ SURV = 1 Sample } \\
\hline & Firms & \% of Sample & Firms & \% of Sample & Firms & \% of Sample \\
\hline 2003 & 44 & 8.87 & 22 & 4.44 & 22 & 4.44 \\
\hline 2004 & 55 & 11.09 & 30 & 6.05 & 25 & 5.04 \\
\hline 2005 & 73 & 14.72 & 44 & 8.87 & 29 & 5.85 \\
\hline 2006 & 75 & 15.12 & 50 & 10.08 & 25 & 5.04 \\
\hline 2007 & 47 & 14.92 & 48 & 9.68 & 26 & 5.24 \\
\hline 2008 & 87 & 17.54 & 60 & 11.28 & 27 & 5.08 \\
\hline 2009 & 88 & 17.74 & 57 & 10.71 & 31 & 5.83 \\
\hline Total & 496 & 100.00 & 311 & 62.70 & 185 & 37.30 \\
\hline
\end{tabular}

Audit firms are required to disclose annual reports, including financial statements, on the homepage of the Financial Supervisory Service of Korea. Financial statement data and information regarding governance structure are manually collected from the annual reports of audit firms. Audit clients' financial data are collected from the KIS-VALUE database of the NICE Information Service. Panel B of Table 1 shows the year distribution of the sample by enforcement action. About 37 percent of the total sample was sanctioned at least once during the current year or the previous year.

\section{Descriptive Statistics}

\section{RESULTS OF THE EMPIRICAL ANALYSIS}

Table 2 presents descriptive statistics for the variables employed in this study.

Table 2. Descriptive Statistics (N=496)

\section{Panel A: Total Samples}

\begin{tabular}{|c|c|c|c|c|c|}
\hline & Mean & Std. & Min & Median & Max \\
\hline$S U R V$ & 0.373 & 0.484 & 0.000 & 0.000 & 1.000 \\
\hline$R E C$ & 0.516 & 0.125 & 0.000 & 0.531 & 0.774 \\
\hline$A F R$ & 0.368 & 0.152 & 0.000 & 0.346 & 0.819 \\
\hline$P A R$ & 0.478 & 0.257 & 0.062 & 0.424 & 1.000 \\
\hline$O W N$ & 0.264 & 0.240 & 0.000 & 0.147 & 0.996 \\
\hline $\mathrm{LHH}$ & 0.285 & 0.147 & 0.200 & 0.222 & 0.993 \\
\hline FYEAR & 0.601 & 0.538 & 0.000 & 0.444 & 2.963 \\
\hline ROS_auditor & 0.032 & 0.030 & -0.111 & 0.030 & 0.146 \\
\hline SIZE_client & 17.032 & 0.302 & 16.145 & 17.031 & 18.021 \\
\hline ROA_client & 0.032 & 0.030 & -0.071 & 0.034 & 0.142 \\
\hline NLIST & 0.121 & 0.076 & 0.009 & 0.105 & 0.357 \\
\hline SIZE_auditor & 8.709 & 1.030 & 5.832 & 8.519 & 12.599 \\
\hline$M E M \bar{M}$ & 0.347 & 0.476 & 0.000 & 0.000 & 1.000 \\
\hline
\end{tabular}


(Table 2 continued)

Panel B: Member Firm vs. Non-member Firm

\begin{tabular}{|c|c|c|c|c|c|c|c|c|}
\hline \multirow[t]{2}{*}{ Variable } & \multicolumn{2}{|c|}{ MEM=1 } & \multicolumn{2}{|c|}{$\mathbf{M E M}=0$} & \multirow[t]{2}{*}{ Mean diff. } & \multirow[t]{2}{*}{$\operatorname{Pr}>|\mathbf{t}|$} & \multirow{2}{*}{$\begin{array}{c}\text { Median } \\
\text { diff. }\end{array}$} & \multirow{2}{*}{$\operatorname{Pr}>|z|$} \\
\hline & Mean & Median & Mean & Median & & & & \\
\hline SURV & 0.593 & 1.000 & 0.256 & 0.000 & -0.337 & $<.0001$ & -1.000 & $<.0001$ \\
\hline$R E C$ & 0.524 & 0.539 & 0.513 & 0.528 & -0.011 & 0.354 & -0.011 & 0.077 \\
\hline$A F R$ & 0.450 & 0.458 & 0.324 & 0.314 & -0.126 & $<.0001$ & -0.144 & $<.0001$ \\
\hline$P A R$ & 0.318 & 0.258 & 0.563 & 0.515 & 0.246 & $<.0001$ & 0.257 & $<.0001$ \\
\hline$O W N$ & 0.259 & 0.130 & 0.266 & 0.167 & 0.008 & 0.730 & 0.037 & $<.0001$ \\
\hline $\mathrm{LHH}$ & 0.279 & 0.229 & 0.288 & 0.222 & 0.009 & 0.506 & -0.007 & 0.238 \\
\hline FYEAR & 0.965 & 0.741 & 0.409 & 0.370 & -0.556 & $<.0001$ & -0.370 & $<.0001$ \\
\hline ROS_auditor & 0.024 & 0.021 & 0.037 & 0.036 & 0.012 & $<.0001$ & 0.016 & $<.0001$ \\
\hline SIZE_client & 17.24 & 17.19 & 16.92 & 16.934 & -0.319 & $<.0001$ & -0.253 & $<.0001$ \\
\hline ROA_client & 0.037 & 0.036 & 0.030 & 0.032 & -0.007 & 0.012 & -0.005 & 0.009 \\
\hline NLIST & 0.153 & 0.147 & 0.105 & 0.083 & -0.049 & $<.0001$ & -0.064 & $<.0001$ \\
\hline SIZE_auditor & 9.489 & 9.113 & 8.294 & 8.320 & -1.194 & $<.0001$ & -0.793 & $<.0001$ \\
\hline
\end{tabular}

Notes: $S U R V_{\mathrm{t}}: 1$ if enforcement action by the FSS was taken in the current or previous years, and 0 otherwise;

$R E C_{\mathrm{t}-1}$ : accounts receivable / total assets in year $\mathrm{t}-1$;

$A F R_{\mathrm{t}-1}$ : audit fee revenue / total revenue in year $\mathrm{t}-1$;

$P A R_{\mathrm{t}-1}$ : number of partners / total number of CPAs in year $\mathrm{t}-1$;

$O W N_{\mathrm{t}-1}$ : ownership percentage of CEO in year $\mathrm{t}-1$;

$L H H_{\mathrm{t}-1}$ : index of ownership concentration computed based on (= ownership of partner with the highest ownership percentage ${ }^{2}+$ ownership of partner with the second-highest ownership percentage ${ }^{2}+$ ownership of partner with the third-highest ownership percentage ${ }^{2}+$ ownership of $^{2}$

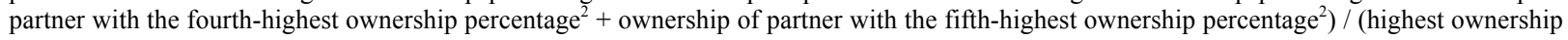
percentage + second-highest ownership percentage + third-highest ownership percentage + fourth-highest ownership percentage + fifth-highest ownership percentage $)^{2}$ in year $\mathrm{t}-1$;

FYEAR $R_{\mathrm{t}-1}$ : number of years from the establishment of an audit firm / average number of years from establishment of all audit firms in year $\mathrm{t}-$ 1 ;

ROS_auditor $\mathrm{t}_{\mathrm{t}-1}$ : net income / total revenue in year $\mathrm{t}-1$;

$S I Z E_{-}$client $_{\mathrm{t}-1}$ : mean value of the natural logarithm of audit clients' total assets for each audit firm in year $\mathrm{t}-1$;

$R O A \_$client $t_{\mathrm{t}-1}$ : mean value of audit clients' return on assets for each audit firm in year $\mathrm{t}-1$;

$N L I S T_{\mathrm{t}-1}$ : number of listed audit clients / total number of audit clients in year $\mathrm{t}-1$;

$S I Z E \_$auditor $r_{\mathrm{t}-1}$ : natural logarithm of an audit firm's total revenue in year $\mathrm{t}-1$;

$M E \bar{M}_{\mathrm{t}-1}: 1$ if an audit firm is affiliated with a foreign multinational audit firm, and 0 otherwise in year $\mathrm{t}-1$; and

$Y D$ : year dummy.

The mean and median values of $R E C$ are 0.516 and 0.531 , respectively, suggesting that over 50 percent of total assets in audit firms consist of receivables. The minimum and maximum values of $R E C$ are 0.000 and 0.774 , respectively. The mean and median values of $A F R$ are 0.368 and 0.346 , respectively, which suggests that about 35 percent of revenues in audit firms is generated from audit services, and around 65 percent of revenues is generated from non-audit services (e.g., consulting, taxation, etc.). The mean and median values of $P A R$ are 0.478 and 0.424 , respectively, indicating that the proportion of partners to the total number of CPAs of an audit firm is around 45 percent. This result suggests that audit partners, on average, experience a heavy burden when working on an audit engagement.

The mean values of $O W N$ and $L H H$ are 0.264 and 0.285 , respectively, which means that CEOs of audit firms own 26 percent of company shares on average, and that the ownership concentration of audit firms is high. The mean value of FYEAR is 0.601 , which means that the average period since establishment of audit firms is 8.11 years (i.e., 0.601 multiplied by the average period of the total sample, which is 13.5). The mean of ROS_auditor is 0.032 , suggesting that audit firms realized about 3 percent return on sales. The mean value of NLIST is 0.121 , showing that about 12 percent of the clients of the sample audit firms are listed companies. The mean value of MEM is 0.347 , indicating that over 30 percent of the sample firms are affiliated with multinational audit firms.

Table 3 presents the Pearson correlation statistics for the variables employed in the regression analyses. 
Table 3. Pearson Correlation Matrix $(\mathrm{N}=496)$

\begin{tabular}{|c|c|c|c|c|c|c|c|c|c|c|c|c|}
\hline & B & C & D & $\mathbf{E}$ & F & G & H & I & $\mathbf{J}$ & $\mathbf{K}$ & $\mathbf{L}$ & M \\
\hline SURV & 0.134 & 0.388 & -0.160 & -0.126 & -0.132 & 0.424 & -0.167 & 0.286 & 0.144 & 0.258 & 0.413 & 0.332 \\
\hline (A) & 0.003 & $<.0001$ & 0.000 & 0.005 & 0.003 & $<.0001$ & 0.000 & $<.0001$ & 0.001 & $<.0001$ & $<.0001$ & $<.0001$ \\
\hline$R E C$ & 1.000 & -0.006 & 0.037 & -0.185 & -0.135 & 0.100 & -0.006 & 0.024 & 0.095 & -0.090 & 0.266 & 0.042 \\
\hline (B) & & 0.887 & 0.407 & $<<.0001$ & 0.003 & 0.027 & 0.889 & 0.598 & 0.035 & 0.046 & $<.0001$ & 0.354 \\
\hline$A F R$ & & 1.000 & -0.241 & -0.170 & -0.116 & 0.475 & -0.194 & 0.428 & 0.099 & 0.220 & 0.324 & 0.394 \\
\hline (C) & & & $<.0001$ & 0.000 & 0.010 & $<.0001$ & $<.0001$ & $<.0001$ & 0.028 & $<.0001$ & $<.0001$ & $\begin{array}{c}<.0001 \\
\end{array}$ \\
\hline$P A R$ & & & 1.000 & -0.339 & -0.285 & -0.307 & 0.115 & -0.435 & -0.093 & -0.387 & -0.385 & -0.456 \\
\hline (D) & & & & $<.0001$ & $<.0001$ & $<.0001$ & 0.011 & $<.0001$ & 0.038 & $<.0001$ & $<.0001$ & $\begin{array}{c}<.0001 \\
\end{array}$ \\
\hline$O W N$ & & & & 1.000 & 0.666 & -0.232 & 0.115 & -0.003 & -0.090 & -0.044 & -0.306 & -0.016 \\
\hline (E) & & & & & $<.0001$ & $<.0001$ & 0.011 & 0.942 & 0.045 & 0.328 & $<<.0001$ & 0.730 \\
\hline$L H H$ & & & & & 1.000 & -0.090 & 0.089 & 0.038 & -0.106 & 0.038 & -0.255 & -0.030 \\
\hline (F) & & & & & & 0.045 & 0.049 & 0.400 & 0.018 & 0.401 & $<.0001$ & 0.506 \\
\hline FYEAR & & & & & & 1.000 & -0.123 & 0.590 & 0.084 & 0.299 & 0.717 & 0.492 \\
\hline (G) & & & & & & & 0.006 & $<<.0001$ & 0.061 & $<<.0001$ & $<.0001$ & $<.0001$ \\
\hline$R O S$ & & & & & & & 1.000 & -0.073 & -0.127 & -0.221 & -0.107 & -0.197 \\
\hline auditor $(\mathrm{H})$ & & & & & & & & 0.103 & 0.005 & $<.0001$ & 0.018 & $<.0001$ \\
\hline SIZE- & & & & & & & & 1.000 & -0.009 & 0.427 & 0.638 & 0.503 \\
\hline client (I) & & & & & & & & & 0.845 & $<.0001$ & $<.0001$ & $<.0001$ \\
\hline$R O A$ & & & & & & & & & 1.000 & 0.068 & 0.169 & 0.113 \\
\hline client $(\mathrm{J})$ & & & & & & & & & & 0.133 & 0.000 & 0.012 \\
\hline NLIST & & & & & & & & & & 1.000 & 0.295 & 0.304 \\
\hline$(\mathrm{K})$ & & & & & & & & & & & $<.0001$ & $<.0001$ \\
\hline SIZE & & & & & & & & & & & 1.000 & 0.553 \\
\hline auditor $(\mathrm{L})$ & & & & & & & & & & & & $<.0001$ \\
\hline$M E M$ & & & & & & & & & & & & 1.000 \\
\hline (M) & & & & & & & & & & & & \\
\hline
\end{tabular}

See Table 2 for the definitions of the variables used.

As expected, SURV is positively correlated with REC, AFR, and FYEAR. These significant positive relationships suggest that greater likelihood of enforcement action is associated with a high receivables ratio, a high proportion of audit fees to total revenue, and longevity of audit firms. In addition, SURV is significantly and negatively correlated with $P A R, O W N, L H H$, and ROS_auditor. These correlations are also consistent with our expectations, as discussed in the Hypotheses development section.

Regarding the control variables, SIZE_client and ROA_client show significant correlations with SURV, indicating that the financial condition of audit clients is related to the likelihood of enforcement action. In particular, $N L I S T$ is significant and positively correlated with $S U R V$, suggesting that the possibility of audit failure increases as the number of listed firms among the audit clients increases. The largest correlations are between FYEAR and SIZE_auditor $(\rho=0.771)$ and $O W N$ and LHH $(\rho=0.666)$. Dropping one of these variables does not change our conclusion. The variance inflation factor scores reveal no severe multicollinearity problems (all scores are less than 4.0).

\section{Empirical Tests of Hypotheses}

Table 4 presents the multivariate analysis of Hypotheses 1 through 7. In order to determine the robustness of the test results, we provide the results of testing using the limited model with $R E C$ and $A F R$ as proxies for independence and $P A R$ as a proxy for auditor expertise in column (1), and the results of testing using another limited model including only $O W N, L H H$, and FYEAR in column (2), as well as the results of testing using the full model with all independent variables in column (3). 
Table 4. Determinants of Enforcement Action of Financial Supervisory Service

\begin{tabular}{|c|c|c|c|c|c|c|c|}
\hline \multirow{2}{*}{\multicolumn{8}{|c|}{$\begin{array}{r}\text { SURV }_{t}=\beta_{0}+\beta_{1} R E C_{t-1}+\beta_{2} A F R_{t-1}+\beta_{3} P A R_{t-1}+\beta_{4} O W N_{t-1}+\beta_{5} L_{H H} H_{t-1}+\beta_{6} F_{Y E A R_{t-1}}+\beta_{7} \text { ROS_auditor }_{t-1} \\
+\beta_{8} \text { SIZE }_{-} \text {client }_{t-1}+\beta_{9} R O A_{-} \text {client }_{t-1}+\beta_{10} N L I S T_{t-1}+\beta_{11} \text { SIZE_auditor }_{t-1}+\beta_{12} M E M_{t-1}+\sum \mathrm{YD} \\
\\
\text { Dependent }=\boldsymbol{S U R \boldsymbol { V } _ { t }}\end{array}$}} \\
\hline & & & & & & & \\
\hline \multirow{2}{*}{ Variables } & \multirow{2}{*}{$\begin{array}{l}\text { Exp. } \\
\text { Sign }\end{array}$} & \multicolumn{2}{|c|}{ (1) } & \multicolumn{2}{|c|}{ (2) } & \multicolumn{2}{|c|}{ (3) } \\
\hline & & Coefficients & $\begin{array}{l}\text { Wald Chi- } \\
\text { Square }\end{array}$ & Coefficients & $\begin{array}{l}\text { Wald Chi- } \\
\text { Square }\end{array}$ & Coefficients & $\begin{array}{l}\text { Wald Chi- } \\
\text { Square }\end{array}$ \\
\hline Intercept & ? & 7.639 & 0.584 & 10.320 & 1.079 & 20.206 & $3.274 *$ \\
\hline$R E C_{t-1}$ & + & 1.855 & $3.377 *$ & & & 2.237 & $4.675 * *$ \\
\hline$A F R_{t-1}$ & + & 5.174 & $31.423 * * *$ & & & 5.013 & $24.049 * * *$ \\
\hline$P A R_{t-1}$ & $+/-$ & 0.867 & $2.923 *$ & & & 1.677 & $6.695 * * *$ \\
\hline$O W N_{t-1}$ & $+/-$ & & & 1.982 & $6.333 * *$ & 3.478 & $14.346^{* * *}$ \\
\hline $\mathrm{LHH}_{t-1}$ & $+1-$ & & & -3.131 & $4.194 * *$ & -2.947 & $4.182 * *$ \\
\hline$F Y Y E A R_{t-1}$ & $+1-$ & & & 2.405 & $17.360 * * *$ & 1.792 & $9.518 * * *$ \\
\hline$R O S \_$auditor $_{t-1}$ & - & & & -8.636 & $4.619 * * *$ & -7.371 & $2.908^{*}$ \\
\hline SIZE_client $t_{t-1}$ & - & -1.175 & $3.426^{*}$ & -0.976 & 2.469 & -1.998 & $7.829 * * *$ \\
\hline ROA_client $t_{t-1}$ & - & 6.614 & 1.777 & 4.694 & 1.140 & 6.560 & 1.711 \\
\hline$N L I S T_{t-1}$ & + & 5.966 & $8.748 * * *$ & 3.430 & 3.285 & 5.920 & $7.438 * * *$ \\
\hline SIZE_auditor $_{t-1}$ & + & 0.856 & $22.159 * *$ & 0.556 & $7.105^{* * *}$ & 0.892 & $13.242 * * *$ \\
\hline$M E M_{t-1}$ & $+/-$ & 0.265 & 0.790 & 0.147 & 0.273 & 0.047 & 0.024 \\
\hline \multicolumn{2}{|l|}{ Year Dummies } & \multicolumn{2}{|c|}{ Included } & \multicolumn{2}{|c|}{ Included } & \multicolumn{2}{|c|}{ Included } \\
\hline \multirow{2}{*}{\multicolumn{2}{|c|}{$\begin{array}{l}\text { Likelihood ratio } \\
\text { Pseudo } \mathrm{R}^{2} \\
\text { Sample Size }\end{array}$}} & \multicolumn{2}{|c|}{$\begin{array}{c}154.02 * * * \\
0.2669\end{array}$} & \multicolumn{2}{|c|}{$\begin{array}{c}146.66 * * * \\
0.2560\end{array}$} & & $\begin{array}{c}179.46 * * * \\
0.3036\end{array}$ \\
\hline & & \multicolumn{2}{|c|}{496} & \multicolumn{2}{|c|}{496} & \multicolumn{2}{|c|}{496} \\
\hline
\end{tabular}

Notes: $* * *, * *$, and $*$ represent significance at the 1,5 , and 10 percent levels, respectively. Variable definitions are presented in Table 2 .

In column (3), Table 4, the proportion of receivables to total assets $(R E C)$ is significant at the 5 percent level. In addition, $A F R$ is significant at the 1 percent level. The results with both $R E C$ and $A F R$ suggest that the risk of audit failure is associated with the level of auditor independence, supporting our Hypotheses 1 and 2 . In column (3), Table 4, PAR is significant at the 1 percent level. This result suggests that as the proportion of partners relative to the total number of CPAs increases, audit firms experience a decline in the number of staff engaging in audits. Also, audit firms place a greater burden on audit team members because of the insufficient number of working staff. As a result, the likelihood of audit failure (measured as enforcement action) increases. This result is in contrast to our expectation that the expertise of audit firms increases when the number of partners with audit experience increases relative to the total number of CPAs. Although the role of partners is to be responsible for final decisions on the issuance of audit opinions, and this decision-making influences audit quality, it is also important to ensure an appropriate number of working staff in order to achieve a high-quality audit. This result supports Hypothesis 3.

In addition, $O W N$ is significant at the 1 percent level. This result indicates that as the ownership of CEOs increases, the likelihood of enforcement action also increases, suggesting that audit firms with high percentages of ownership by CEOs may experience less effective governance in ensuring quality audits. In addition, $L H H$ is negative and significant at the 5 percent level, suggesting that as the ownership concentration increases, the likelihood of enforcement action decreases. These results support Hypotheses 4 and 5.

We find a positive association of FYEAR with the likelihood of enforcement action at the 1 percent significance level, suggesting that the longer the period of engagement of auditors is, the higher the likelihood of audit failure is. This result may suggest that newly established audit firms pay more attention to audit risk and allocate more resources to each engagement to ensure quality audits more frequently than older firms when competition in the audit market is fierce. This result supports Hypothesis 6.

The coefficient of ROS_auditor is -7.371 , which is significant at the 10 percent level, indicating that the higher the profitability of an audit firm is, the lower the risk of audit failure. A low value of ROS_auditor indicates that audit firms are operating at the margin and therefore are unable to guarantee sufficient profits to hire highquality personnel and invest adequately in technology to maintain high audit quality. In summary, these results 
Table 6. Additional Test Results

\begin{tabular}{|c|c|c|c|c|c|}
\hline \multirow{4}{*}{ Variables } & \multirow{4}{*}{$\begin{array}{l}\text { Exp. } \\
\text { sign }\end{array}$} & \multicolumn{4}{|c|}{ 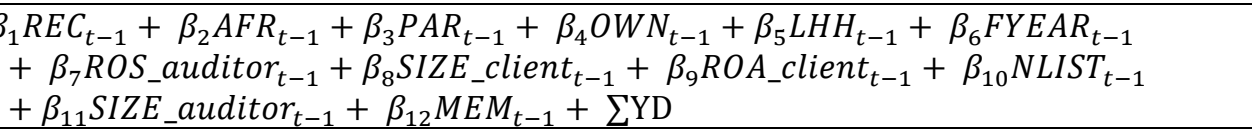 } \\
\hline & & \multicolumn{4}{|c|}{ Dependent $=$ SURV } \\
\hline & & \multicolumn{2}{|c|}{ (1) $\mathrm{MEM}=0$ sub-sample } & \multicolumn{2}{|c|}{ (2) $\mathrm{MEM=1} \mathrm{sub-sample}$} \\
\hline & & Coefficients & Wald Chi-Square & Coefficients & Wald Chi-Square \\
\hline intercept & $?$ & 31.082 & 5.202 & -8.762 & 0.095 \\
\hline$R E C_{t-1}$ & + & 1.870 & 1.864 & 2.400 & 1.383 \\
\hline$A F R_{t-1}$ & + & 4.151 & $9.666 * * *$ & 6.502 & $9.194 * * *$ \\
\hline$P A R_{t-1}$ & $+/-$ & 1.993 & $6.982 * * *$ & 2.042 & 1.658 \\
\hline$O W N_{t-1}$ & $+/-$ & 4.211 & $13.436 * * *$ & 3.120 & 1.929 \\
\hline $\mathrm{LHH}_{t-1}$ & $+/-$ & -3.667 & $5.316 * *$ & -0.431 & 0.008 \\
\hline$F Y Y E A R_{t-1}$ & $+/-$ & 1.475 & $3.394^{*}$ & 3.272 & $5.247 * *$ \\
\hline$R O S \_$auditor $_{t-1}$ & - & -6.156 & 1.067 & -10.277 & 1.615 \\
\hline SIZE_client $t_{t-1}$ & - & -2.576 & $8.938 * * *$ & -0.399 & 0.050 \\
\hline$R O A \_$client $_{t-1}$ & - & 8.765 & 2.084 & -13.569 & 1.909 \\
\hline$N L I S T_{t-1}$ & + & 4.299 & $2.904 *$ & 14.657 & $5.453 * *$ \\
\hline SIZE_auditor $_{t-1}$ & + & 0.813 & $5.166 * *$ & 0.738 & 2.667 \\
\hline Year Dummies & & & ded & & ded \\
\hline Likelihood ratio & & & $4 * * *$ & & $5 * * *$ \\
\hline Pseudo $\mathrm{R}^{2}$ & & & 359 & & 548 \\
\hline Sample Size & & & & & \\
\hline
\end{tabular}

Notes: $* * *, * *$, and $*$ represent significance at the 1,5 , and 10 percent levels, respectively. Variable definitions are presented in Table 2 .

While $P A R$ is positive and significant at the 1 percent level in the non-affiliated firms, it is not significant in the sample of affiliated firms. This result suggests that the negative effect on audit quality of insufficient numbers of staff engaging in audits appears to be a problem among audit firms that are not affiliated with multinationals. This may be because affiliated firms are likely to have systematic audit procedures and control systems to ensure audit quality. In addition, the values for $O W N$ and $L H H$ are statistically significant only for non-affiliated firms, suggesting that the governance structure of audit firms influences the quality of audits only for firms that are not affiliated with multinational audit firms.

\section{CONCLUSION}

In this study, we investigate the determinants of audit failure from the perspective of audit firms. While audit risk is the joint probability of inherent, control, and detection risk, most previous studies focused on inherent and control risk only, which are client-specific. Audit firm characteristics have not been thoroughly examined, possibly because relevant audit firm data is not publicly available. Detection risk, which is audit firm-specific, varies depending on certain audit firm characteristics directly related to audit quality.

In this study, we argue that audit quality is determined by firm independence, expertise, governance, and ownership structure. We find that the proportion of accounts receivable to total assets is positively associated with audit failure. This result implies that audit firm independence can improve audit quality. We also find that the proportion of audit fees to total revenue is positively associated with audit failure. This result suggests that a heavy dependence on audit fees in revenue structure may be undesirable from the viewpoint of maintaining audit quality. We find that the proportion of partners to the total number of CPAs is positively associated with audit failure. This result suggests that audit firms must assign sufficient staff to each engagement to maintain audit quality.

We find that CEO ownership is positively associated with audit failure, while ownership concentration in the top five partners is negatively associated with audit failure. These results suggest that while ownership concentrated among several partners may improve audit effectiveness, the significant influence of a single CEO in 
audit firms may not improve audit quality. These results may be related to the fact that each partner brings a certain synergy and expertise to the audit firm. We also find that the number of years from establishment of the firm (longevity) is positively associated with audit failure, while audit firm profitability is negatively associated with audit failure. The positive association between longevity and audit failure may simply reflect the fact that established audit firms become overconfident in performing audits. Further details about the client portfolio across the years and other audit firm characteristics may be elucidated in future research. The negative association between profitability and audit failure suggests that it is important for audit firms to earn reasonable profits in order to maintain audit quality. Finally, we find that the results of this study are more pronounced with audit firms that are not affiliated with multinational audit firms than with those that are, possibly because these firms do not have access to pertinent technology and/or knowledge available from multinational audit firms to maintain quality.

By identifying several characteristics of audit firms that affect audit failure, we provide several useful implications to regulators who desire to improve audit quality. The results of our study suggest that improvement of audit quality can be achieved by changing certain audit firm characteristics. Future study may examine more details of audit firm characteristics that affect the default risk of audit firms and risk premiums paid to insurance firms.

\section{AUTHOR INFORMATION}

Min-Jung Kang, Ph.D., Assistant Professor, Business Administration , Incheon National University, 119 Academiro, Yeonsu-gu, Incheon 406-772, South Korea. E-mail: mjkang@inu.ac.kr

Ho-Young Lee, Ph.D., Professor, School of Business, Yonsei University, 50 Yonsei-ro, Seodaemun-gu, Seoul 120749, South Korea. E-mail: hylee@yonsei.ac.kr

Yong-Sang Woo, Ph.D. Assistant Professor, The College of Business Administration, Ewha Womans University, 52 Ewhayeodae-gil, Seodaemun-gu, Seoul 120-750, South Korea. E-mail: yswoo@ewha.ac.kr (Corresponding author)

\section{REFERENCES}

Abbott, L., S. Parker, and G. Peters. 2006. Earnings Management, Litigation Risk, and Asymmetric Audit Fee Responses. Auditing: A Journal of Practice \& Theory 25 (1): 85-98.

Balsam, S., J. Krishnan, and J. Yang. 2003. Auditor Industry Specialization and Earnings Quality. Auditing: A Journal of Practice and Theory 22 (2003): 71-97.

Beasley, M. 1996. An Empirical Analysis of the Relation between Board of Director Composition and Financial Statement Fraud. The Accounting Review 71(October): 443-465.

Bell, T., W. Landsman, and D. Shackelford. 2001. Auditors' Perceived Business Risk and Audit Fees: Analysis and Evidence. Journal of Accounting Research 39(1): 35-43.

Beneish, M. 1999. Incentives and Penalties Related to Earnings Overstatements that Violate GAAP. The Accounting Review 74(4): 425-457.

Casterella, J., K. Jensen, and W. Knechel. 2010. Litigation Risk and Audit Firm Characteristics. Auditing: A Journal of Practice \& Theory 29 (2): 71-82.

DeAngelo, L.1981. Auditor size and audit quality. Journal of Accounting and Economics 3: 183-199.

Dechow, P., R. Sloan, and A. Sweeney. 1996. Causes and Consequences of Earnings Manipulations: An Analysis of Firms Subject to Enforcement Actions by the SEC. Contemporary Accounting Research 13(Spring): 1-36.

DeFond, M. and J. Jiambalvo. 1994. Debt Covenant Violation and Manipulation of Accruals. Journal of Accounting and Economics 17(January): 145-176.

Feroz, E., K. Park, and V. S. Pastena. 1991. The Financial and Market Effects of the SEC's Accounting and Auditing Enforcement Releases. Journal of Accounting Research 29(Supplement): 107-142.

Healy, P. and K. Palepu. 1990. Effectiveness of Accounting-Based Dividend Covenants. Journal of Accounting and Economics 12(January): 97-124.

Hermanson, D., R. Houston, and J. Rice. 2007. PCAOB Inspections of Smaller CPA Firms: Initial Evidence from Inspection Reports. Accounting Horizons 21(2): 137-152.

Jensen, M., and W. Meckling. 1976. Theory of the Firm: Managerial Behavior, Agency Costs and Ownership Structure. Journal of Financial Economics 3(4): 305-360. 
Klein, A. 2002. Audit Committee, Board of Director Characteristics, and Earnings Management. Journal of Accounting and Economics 33(August): 375-400.

Lennox, C. 1999. Audit quality and auditor size: An evaluation of reputation and deep pockets hypotheses. Journal of Business Finance \& Accounting 26(7 \& 8): 779-805.

Linville, M., and J. Thornton. 2001. Litigation risk factors as identified by malpractice insurance carriers. The Journal of Applied Business Research 17(4): 93-105.

Lys, T., and R. Watts. 1994. Lawsuits against auditors. Journal of Accounting Research 32: 65-93.

Maijoor, S., and A. Vanstraelen. 2012. “Research Opportunities in Auditing in the EU," Revisited. Auditing: A Journal of Practice \& Theory 31(1): 115-126.

Nourayi, M. 1994. Stock Price Responses to the SEC's Enforcement Actions. Journal of Accounting and Public Policy 13: 333-347.

Palmrose, Z. 1988. An Analysis of Auditor Litigation and Audit Service Quality. The Accounting Review 63(1): 5573.

Pratt, J., and J. Stice. 1994. The Effects of Client Characteristics on Auditor Litigation Risk Judgments, Required Audit Evidence, and Recommended Audit Fees. The Accounting Review 69(4): 639-656.

Public Company Accounting Oversight Board (PCAOB). 2010. Auditing Standard No. 8, Audit Risk. PCAOB, Washington, D. C.

Schultz, J. and S. Gustavson. 1978. Actuaries' Perceptions of Variables Affecting the Independent Auditor's Legal Liability. The Accounting Review (July): 624-641.

Stice, J. 1991. Using financial and market information to identify pre-engagement factors associated with lawsuits against auditors. The Accounting Review 66: 516-534.

St. Pierre, K., and J. Anderson. 1984. An Analysis of the Factors Associated With Lawsuits Against Public Accountants. The Accounting Review (April): 242-263.

White, H. 1984. Asymptotic Theory for Econometricians. Orlando, FL: Academic Press. 